\title{
Transition of Natural Pedology into Man Made Anthropedogenesis through Anthropocene Epoch- A review
}

\author{
VR. Mageshen ${ }^{* 1}$, S. Meena ${ }^{2}$, P. Santhy ${ }^{3}$, MR. Latha ${ }^{4}$ \\ ${ }^{*}$ PhD Scholar, Department of Soil Science and Agricultural Chemistry, Tamil Nadu \\ Agricultural University, Coimbatore-641 0033, India \\ 2,3,4 Professor, Department of Soil Science and Agricultural Chemistry, Tamil Nadu \\ Agricultural University, Coimbatore-641 003, India \\ Corresponding author Email Id: mageshsmart2@gmail.com
}

\begin{abstract}
The renowned science of pedology, which commenced in the nineteenth century as a study of natural processes in soil formation, is adapting to the demands of the Anthropocene, the geologic period during which planet Earth and its soils change from natural to humannatural systems. The term Anthropocene comes from the Greek words anthropos, which means "man," and cene, which means "new." Within the Geological Time Scale, the 'Anthropocene' is not yet a formally recognised geological unit. The Anthropocene Working Group (AWG) is working on a proposal to codify the word for discussion. Anthropedogenic processes are characterised as artificial settings that dramatically alter natural soil formation processes or causes. In any given setting, human actions alter one or more of the five soil-forming factors. Given that humans differ from other organisms in that they purposefully manage soils independently of other soil-forming variables, and because they employ technology to affect soils on a far larger scale than other organisms. Humans' collective impacts on soil development have been categorised as a sixth soil-forming component. The basic science of pedology, the study of natural soil formation, is evolving into the science of anthropedogenesis in the Anthropocene. The future of pedology is a resurgent discipline known as anthropedology, which draws on previous pedology but moves from "human as outsider" to "human as insider." In other words, in pedology, the human must transform from a soil-disturbing to a soil-forming agent.
\end{abstract}

Keywords: Anthropocene, Humans, Anthropedogenesis, Insider, Forming

\section{Introduction:}

"It is impossible to care for each other more or differently than we care for the earth" -Wendell Berry

Among the millions of life forms on our planet, the human species has the most influence on the earth's ecosystems and biogeochemistry. From the composition of the atmosphere to the temperature of the oceans, the imprint of human activities can be found everywhere. Farming is thought to be the largest human footprint on the earth, disrupting most quasi-steady state soil processes profoundly. (Amundson et al., 2015). Soils in the world's most distant locations today contain radioisotopes from nuclear devices and xenobiotic substances from the chemical industry; soils exposed by tillage and building 
around the world degrade at rates more than 100 times faster than before they were touched by humans. Plow layer Ap horizons could now be found in broad swaths of the continent's soils, and many of them retain less than half of their original organic matter supply. Rice cultivation has resulted in the creation of millions of hectares of artificial wetland soils, mostly in the subtropics. Artificial drainage, on the other hand, has ruined millions of hectares of natural wetlands, primarily in milder climates. (Weil and Rc Brady, 2017). Because of these and other developments, scientists today believe that the earth slid beyond the Holocene Epoch and into a geologic epoch known as the Anthropocene in the last century or so (the age of humans).

Table1.Official Timeline of earth

\begin{tabular}{|l|l|l|}
\hline \multirow{2}{*}{ Earth } & Eons (Four eons) & $\begin{array}{l}\text { Most recent (Phanerozoic) - Revealed life - } \\
\text { 541Million Years ago(Mya) }\end{array}$ \\
\cline { 2 - 3 } & Eras & $\begin{array}{l}\text { Paleozoic (Era of tribolites - Arthropods) } \\
\text { Mesozoic (Era of dinosaurs) } \\
\text { Cenozoic (Era of Mammals and Birds) }\end{array}$ \\
\cline { 2 - 3 } & Periods (50 Mya/period) & $\begin{array}{l}\text { Paleogene (66-23.03 Mya) } \\
\text { Neogene (23.03 - 2.588 Mya) } \\
\text { Quaternary (2.588- present) }\end{array}$ \\
\cline { 2 - 3 } & Epochs (ten million \\
years) & $\begin{array}{l}\text { Pleistocene Epoch (2.588 Mya - 11.700 ya) } \\
\text { Holocene Epoch } \\
\text { Anthropocene Epoch }\end{array}$ \\
\cline { 2 - 3 } & Ages & $\begin{array}{l}\text { Upper, middle, Calabrian and gelasian for } \\
\text { pleistocene }\end{array}$ \\
\hline
\end{tabular}

The term "Anthropocene" was invented by Eugene Stor

Source: Yadvinder Malhi, 2017 ascribed to Paul Crutzen, a Dutch chemist and Nobel Laureate in Chemistry in 1995, for introducing it to people's attention at a conference in 2000. (Crutzen and Stoermer, 2000; Crutzen, 2002). The term Anthropocene comes from the Greek words anthropos, which means "man," and cene, which means "new." It refers to the period of geologic time when the Earth changes from a naturalistic to a human-natural planet. The International Commission on Stratigraphy, which regulates how we talk about Earth's past, has the authority to name and define geological epochs. They're still disputing whether the Anthropocene has been proven, and they're hunting for a 'golden spike,' a fossil marker that might distinguish the Holocene from the Anthropocene. The Earth's official timeline is divided into epochs. The International Commission on Stratigraphy divides the 4.6 billion years into Eons, Eras, Periods, Epochs, and Ages. The Phanerozoic, which commenced 540 million years ago, is the current Eon. The Holocene, Earth's current epoch, began roughly 12,000 years ago, with the conclusion of the last ice age. 


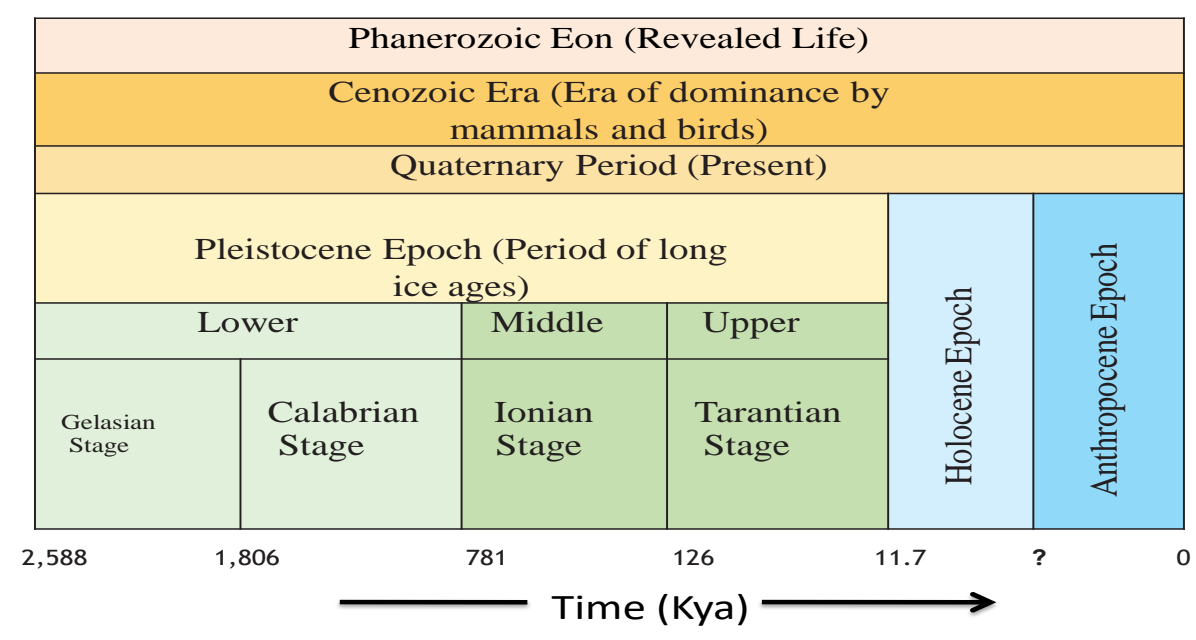

Fig 1.Geological time scale

\section{Transition from pedology to anthropedology}

Table 2.Timeline for Transition from pedology to anthropedology

\begin{tabular}{|l|l|}
\hline \multicolumn{1}{|c|}{ Year } & \multicolumn{1}{|c|}{ Contributions } \\
\hline $1850-1890$ & $\begin{array}{l}\text { E. W. Hilgard (1860) and Vasily Dokuchaev defined Soils as } \\
\text { natural bodies, as fundamental parts of nature }\end{array}$ \\
\hline $1890-1936$ & $\begin{array}{l}\text { Pedology is a natural and basic science that focuses nearly } \\
\text { entirely on natural soil formation variables and processes. }\end{array}$ \\
\hline $1937-1990$ & $\begin{array}{l}\text { The eight versions of Nature and Soil Properties Promoted } \\
\text { pedology as a fundamental science and a "soil science in its } \\
\text { purest form." }\end{array}$ \\
\hline 1941 & $\begin{array}{l}\text { Jenny was attracted by human soil change and included human } \\
\text { influence in the Dokuchaev-Jenny state factor equation's } \\
\text { biological element. S=f(c,l,o,p,t...). He said "Cultivation and } \\
\text { fertilizing of soils, as well as crop removal, are extensively } \\
\text { practiced acts that brand man as an outstanding biological soil- } \\
\text { forming component," }\end{array}$ \\
\hline 1950 & $\begin{array}{l}\text { Many soil scientists were uninterested in human-soil connections } \\
\text { and saw human activities as simply interfering with soil } \\
\text { production. If pedologists thought about human influence at all, } \\
\text { they thought of it as a biological aspect. }\end{array}$ \\
\hline 1960 & $\begin{array}{l}\text { Soil scientists are progressively including the human component } \\
\text { into pedology. }\end{array}$ \\
\hline $\begin{array}{l}\text { Anthropedology began to grow as the environmental sciences } \\
\text { began to permeate pedology. }\end{array}$ \\
\hline The International Committee on Anthropogenic Soils \\
\hline 1980
\end{tabular}




\begin{tabular}{|l|l|}
\hline & $\begin{array}{l}\text { (ICOMANTH) was formed to develop an anthrogenic soil } \\
\text { classification system inside the Soil Taxonomy system. }\end{array}$ \\
\hline 1990 & $\begin{array}{l}\text { Global soil change-described and analysed how human } \\
\text { activities were changing natural soils. Anthropedology research } \\
\text { has exploded in popularity. }\end{array}$ \\
\hline 1998 & $\begin{array}{l}\text { First edition of WRB published with 30 RSG (including } \\
\text { anthrosols) }\end{array}$ \\
\hline 2006 & $\begin{array}{l}\text { Second Edition of WRB published with 32 RSG (Technosols and } \\
\text { stagnosols) }\end{array}$ \\
\hline 2009 & $\begin{array}{l}\text { Jan Zalasiewicz and colleagues proposed the Anthropocene } \\
\text { Epoch as a defined geological interval for the first time. }\end{array}$ \\
\hline 2012 & $\begin{array}{l}\text { Establishment of Anthropocene Working Group (AWG) } \\
\text { human influence on soil taxa in the past. }\end{array}$ \\
\hline 2014 & $\begin{array}{l}\text { In 2014, the ICOMANTH Final Recommendation was accepted, } \\
\text { complete with photos of landfill and rice paddy soils on the cover } \\
\text { of the 2014 Keys to Soil Taxonomy. }\end{array}$ \\
\hline 2016 & $\begin{array}{l}\text { At the 35th International Geological Congress, the Anthropocene } \\
\text { Working Group of the International Union of Geologic Sciences } \\
\text { (IUGS) voted to recommend the Anthropocene as a legitimate } \\
\text { geologic era. }\end{array}$ \\
\hline
\end{tabular}

Sources: Richer et al., 2015 \& 2020

This interval must first be approved by the IUGS and the International Commission on Stratigraphy before it can be made official.

Significantly, the transition from pedology to anthropedology is forged not only by Steffen et al (2015).Great Acceleration, but also by numerous pedological studies that have investigated the diachronous beginnings of human influences on soil, particularly during the time when human influence was traditionally considered to be local and part of the state factor equation's trailing dots. (Sandor, 2006; Warkentin, 2006; Edgeworth et al., 2015; Schaetzl and Thompson, 2015). Soil scientists have chronicled the long history of human-soil relations in Africa, Asia, Europe, and the Americas on local to regional scales. (McNeill and Winiwarter, 2004).

\section{Different depiction for defining transition from Holocene to anthropocene epoch:}

\subsection{Ball and cup depiction of earth system}

The Holocene envelope of natural variability and basin of attraction is depicted as a ball and cup (Stefen et al., 2016). The basin of attraction is more difficult to define than the envelope of variability, thus its position (Figure 2) is useful in conceptualizing the Earth System method to identifying the Anthropocene. 


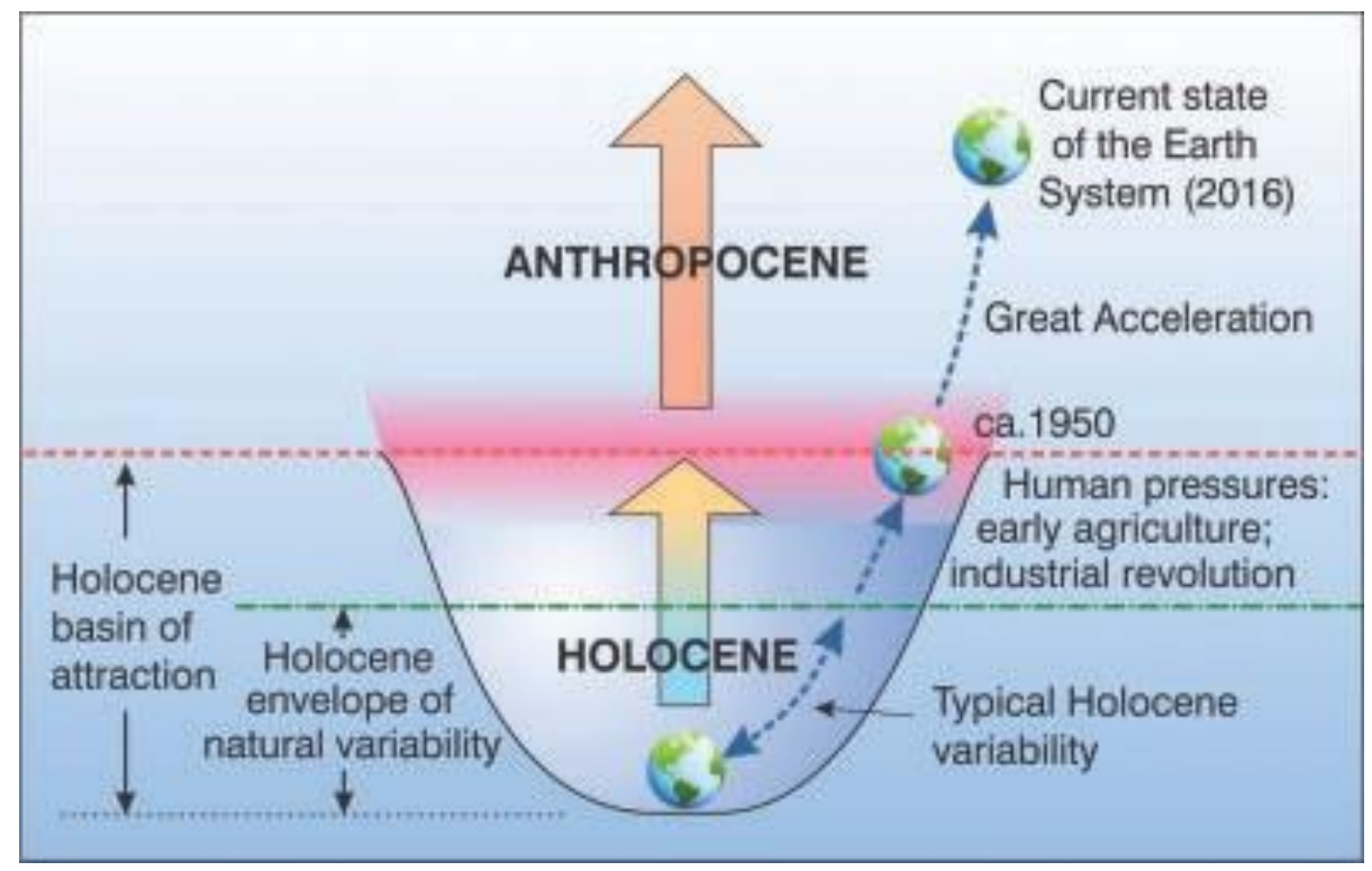

Fig 2.Ball and cup depiction of earth system

The Holocene natural variability envelope depicts the Earth System's natural variability limit (e.g., climatic and intrinsic biosphere variability that occurs in the absence of major human perturbations). Up to a point, perturbations of the Earth System, such as those driven by more intensive human activity of agriculture and then the industrial revolution, can push the Earth beyond the limits of natural variability while remaining within the Holocene basin of attraction, that is, within a state of the Earth System that is still structurally and functionally recognizable as the Holocene and within which negative feedbacks are still dominant. The developing human pressures are located between the Holocene envelope of variability and the top of the Holocene basin of attraction, signifying a period of increasing human activity that is moving the Earth System toward, but not yet into, the Anthropocene. The area below the broken red line indicates the stratigraphic Holocene Epoch, whereas the area above the broken red line indicates the stratigraphic Anthropocene Epoch. The Earth System Anthropocene is depicted as a trajectory away from the Holocene, not as a stable state.

\subsection{Ball and cup depiction of regime shift}

A dynamic variation of the ball-and-cup metaphor can be used to show the transition from the Holocene to the Anthropocene (Figure 3). The Earth System must be tilted out of the basin of attraction of its current state, the Holocene, to experience a regime change and transition to another stable state (Stefen et al., 2016). Alternatively, manmade forcings significantly alter the present basin of attraction, eliminating the likelihood of a return to the Holocene. The basin of attraction is deep in the early to mid-Holocene, but as human perturbations of the Earth System rise due to agricultural expansion and later the industrial revolution, the Holocene basin of attraction becomes increasingly shallow. The orange ball 
depicts the condition of the Earth System, while the cup on the right represents a stable basin of attraction (the Holocene). The pink ball and the cup on the left indicate a hypothetical state of the Earth System (the Anthropocene). The cup becomes deeper and eventually evaporates as a result of human force, causing the ball to roll to the left.

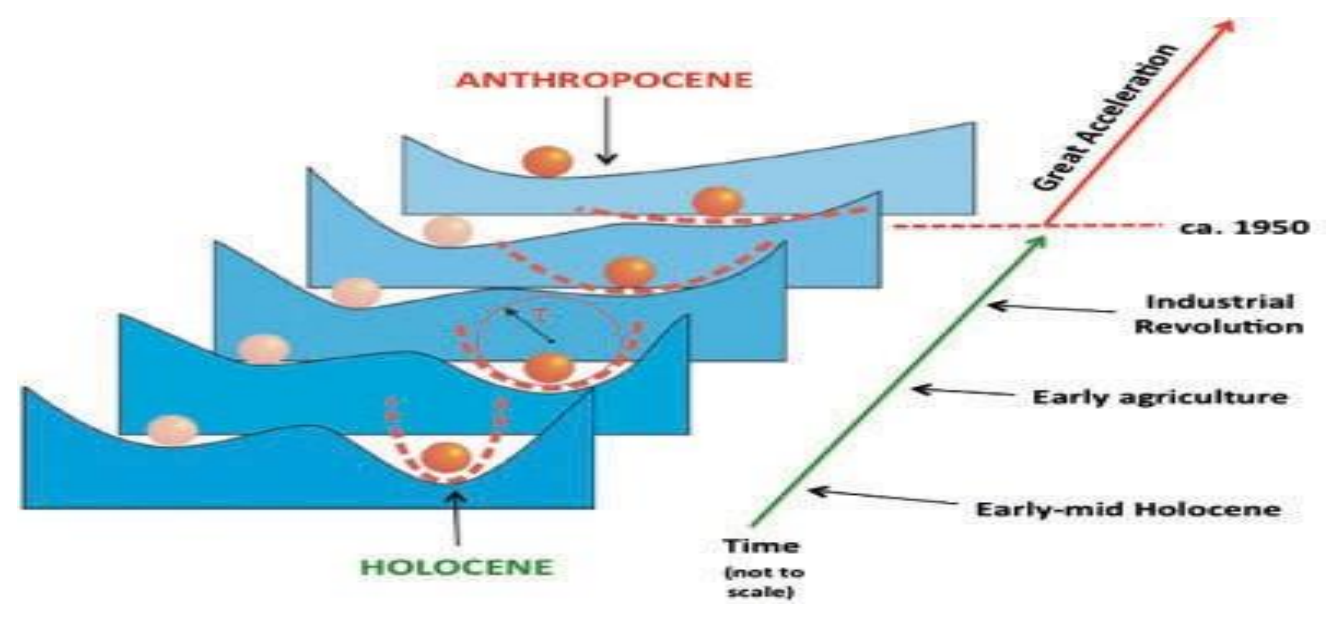

Fig 3.Ball and cup metaphor

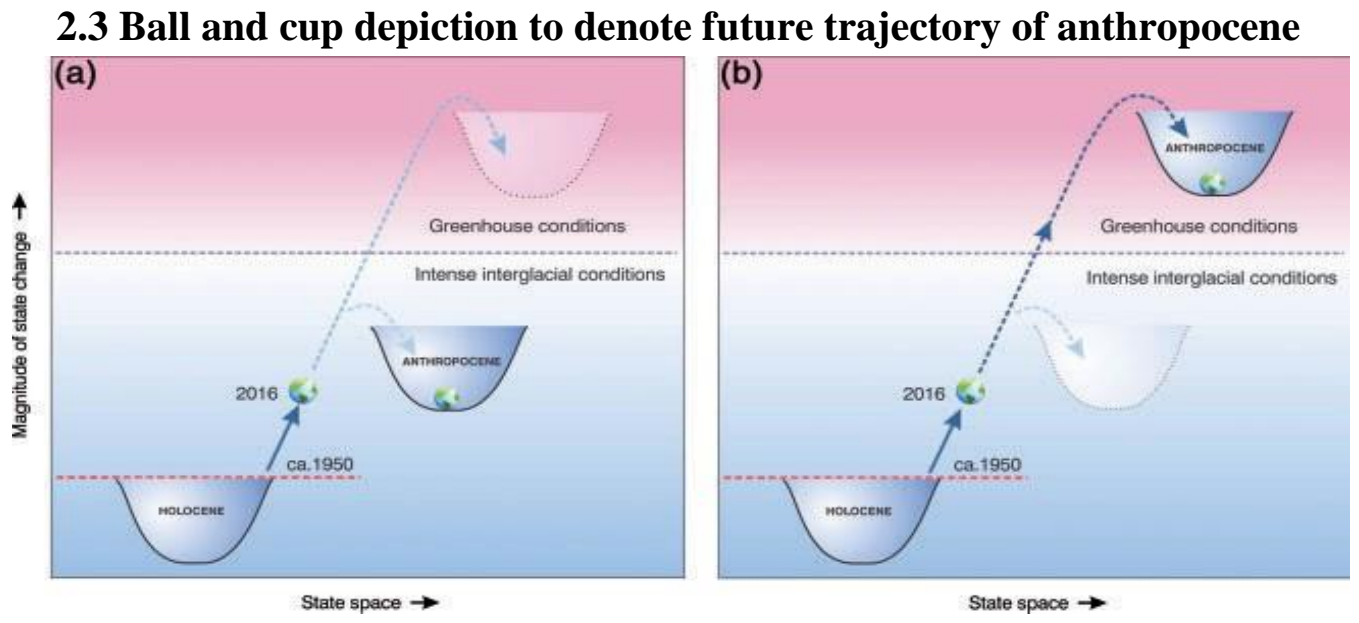

Fig 4.Future trajectory of anthropocene

The vertical axis depicts the magnitude of change in the Earth System as measured by climate and biosphere indicators, while the horizontal axis depicts the system's state space (Steffen et al., 2018). The Anthropocene state is distinguished from the Holocene state by its location. The Anthropocene hypothetical states (cups) describe distinct modes of functioning of the Earth System that occur when the system's highly transient phase ends and more stable conditions emerge. We believe that these more stable settings will last for millennia within a certain range of inherent unpredictability. Figure 4(a) shows a swift and significant reduction in greenhouse gas emissions, as well as a significant shift in human exploitation of the biosphere. In comparison to contemporary conditions, biodiversity does not appear to be declining significantly. Figure 4 (b) depicts a full-fledged Anthropocene scenario in which human impacts on the climate continue to rise. 


\section{Basic Mechanism for formation of anthropogenic soils}

$\checkmark$ Burying a natural soil beneath one or more layers of impermeable material that has been artificially produced (e.g., concrete pavement).

$\checkmark$ Transformation of a natural soil by human action (metagenetic), or

$\checkmark$ Human action, usually with the help of mechanical equipment (neogenetic), creates and deposits a new soil profile in parent materials (anthrosediments) (Howard, 2017).
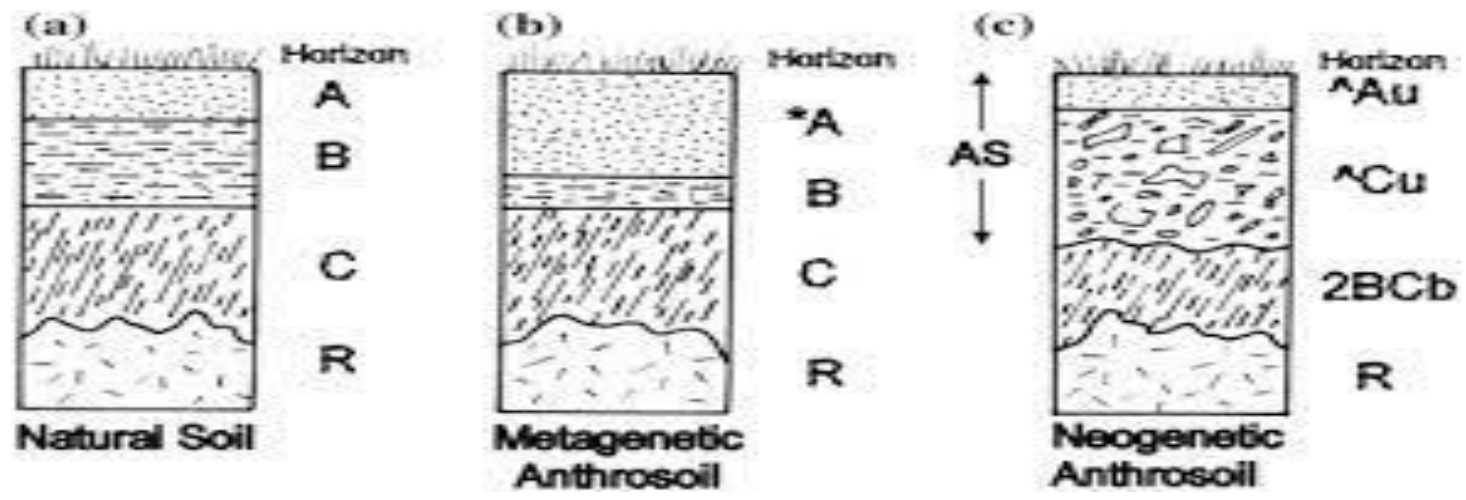

Fig 5.Anthropogenic soil formation

\section{Anthrosediments (Anthropogenic sediments)}

These are sedimentary deposits that have been created via an artificial sedimentation method. An anthropogenic sedimentary deposit (anthrosediment) is generated when soil and other earth components are extracted, transported about, then backfilled with building demolition rubble. Anthrosoil is the soil profile formed by these artificial parent materials. Natural materials (mine spoils, excavated soil, rock or regolith, etc.) may be mixed with artificial materials (brick, mortar, concrete, slag, etc.) in human-deposited parent material. Human activity has the ability to raise or decrease natural sedimentation rates. Overgrazing by farm animals or construction in a drainage basin, for example, can speed up soil erosion, resulting in an increase in the volume of river material downstream. Dam construction, on the other hand, may result in a significant reduction in sediment volume in a drainage basin downstream of the dam.

Because the mechanism of sedimentation is natural, only the pace of deposition is changed indirectly by human action, these sedimentary deposits are not anthrosediments. It is likewise difficult to distinguish such sediments from those of entirely natural origin in the field. As a result, anthropogenic soils and sediments will be referred to as anthrosoils and anthrosediments, respectively (Howard, 2017).

Four types of anthrosoil can be distinguished by their geocultural setting and historical context: (1) Agricultural, (2) Archaeological, (3) Mine-related, and (4) Urban. Anthrosoils in agricultural and archaeological settings were the focus of early scientific investigations dating back to the late 19th century, whereas urban and mine-related anthrosoils were only studied in the late 20th century. In the domains of agronomy and archaeology, the study of anthrosoils is critical, whereas studies of urban and mine-related soils are frequently concerned with environmental concerns. 


\section{Anthropedogenic processes}

Anthropedogenic processes are characterised as artificial settings that dramatically alter natural soil formation processes or causes. Pedogenesis is frequently accelerated or disrupted by human activities, yet many anthropogenic processes can be classified using the same language as natural soil-forming processes. Human activities can have direct or indirect consequences, with reversible or irreversible consequences. They range from tiny alterations at archaeological sites caused by humans employing archaic tools or animal labour (e.g., a wooden plough) to major changes caused by massive pieces of automated equipment employed in modern agriculture, mining, and urbanisation.

Human actions can influence weathering and horizonation. Human alterations that impact the drainage characteristics of the soil might speed up or slow down weathering. Irrigation agriculture or the use of a sprinkler system, for example, can speed up leaching and weathering, whereas compaction or the use of a constructed layer can slow or stop it. Human activities can alter horizonation through affecting contributions, losses, translocations, and transformations in the soil.

Table 3.Comparison between natural and anthropogenic soil-forming processes

\begin{tabular}{|c|c|c|}
\hline Pedogenic process & Natural Example & Anthropogenic Example \\
\hline \multicolumn{3}{|l|}{ Additions to the soil } \\
\hline Enrichment & $\begin{array}{l}\text { Plant nutrients added via } \\
\text { Organic matter decomposition }\end{array}$ & $\begin{array}{l}\text { Chemical elements } \text { added } \\
\text { runoff, acid rain, fertilizer } \\
\text { additions }\end{array}$ \\
\hline Littering & Organic litter on forest floor & $\begin{array}{l}\text { Artificial mulch used in } \\
\text { gardening and landscaping }\end{array}$ \\
\hline \multicolumn{3}{|l|}{ Losses from the soil } \\
\hline Erosion & $\begin{array}{l}\text { Cut bank of meandering } \\
\text { Stream }\end{array}$ & $\begin{array}{l}\text { Excavation for building } \\
\text { construction, borrow pit, } \\
\text { highway, surface mine, etc }\end{array}$ \\
\hline Leaching & Seasonal snowmelt & Irrigation; lawn sprinklers \\
\hline \multicolumn{3}{|c|}{ Translocation within the soil } \\
\hline Pedoturbation & Ground squirrel burrows & $\begin{array}{l}\text { Surface mine or demolition site } \\
\text { grading, excavation, and } \\
\text { backfilling (anthroturbation) }\end{array}$ \\
\hline \multicolumn{3}{|c|}{ Transformations within the soil } \\
\hline Mineralization & $\begin{array}{l}\text { Release goethite from } \\
\text { decomposed humic materials }\end{array}$ & $\begin{array}{l}\text { Release of magnetite from } \\
\text { decomposed fly Ash }\end{array}$ \\
\hline Loosening & $\begin{array}{l}\text { Pedoturbation by indigenous } \\
\text { earthworm species; plant root } \\
\text { development }\end{array}$ & $\begin{array}{l}\text { Plowing; burrowing by invasive } \\
\text { species of Earthworms }\end{array}$ \\
\hline Hardening & Microbiotic crust formation & $\begin{array}{l}\text { Compaction by farm } \\
\text { earthmoving equipment }\end{array}$ \\
\hline
\end{tabular}


Table 4.Classification and impacts of human activities on soil properties

\begin{tabular}{|c|c|}
\hline Anthropogenic Activities & Impact on soil \\
\hline \multicolumn{2}{|l|}{ Physical } \\
\hline Excavation & $\begin{array}{l}\text { Part or all of the old soil is removed; new parent } \\
\text { material is exposed; earth materials are mixed; } \\
\text { hydrological conditions are altered; and the microbial } \\
\text { community is destroyed. }\end{array}$ \\
\hline Construction & $\begin{array}{l}\text { Mixing of earth elements; soil burial; alteration of } \\
\text { hydrological conditions; microbial population } \\
\text { annihilation }\end{array}$ \\
\hline Compaction & $\begin{array}{l}\text { Decreased aeration, leaching and translocation; } \\
\text { reduction of microbial population }\end{array}$ \\
\hline Cultivation, plowing & $\begin{array}{l}\text { Mixing of the surface horizon; destruction of soil } \\
\text { structure; increased soil erosion }\end{array}$ \\
\hline Terracing & Modified hydrological conditions \\
\hline $\begin{array}{l}\text { Dam construction on } \\
\text { Floodplains }\end{array}$ & $\begin{array}{l}\text { Reduction of sedimentation and leaching; lowering of } \\
\text { water table }\end{array}$ \\
\hline \multicolumn{2}{|l|}{ Chemical } \\
\hline Fertilizers & Change plant nutrient content and $\mathrm{pH}$ \\
\hline $\begin{array}{l}\text { Additions of organic wastes, } \\
\text { charcoal, biochar, etc. }\end{array}$ & $\begin{array}{l}\text { Improved aeration and water-holding capacity; } \\
\text { increased cation exchange capacity; alteration in the } \\
\text { composition of organic soil components }\end{array}$ \\
\hline Acid rain & Accelerated leaching of plant nutrients \\
\hline \multicolumn{2}{|l|}{ Mineralogical } \\
\hline Ponding & $\begin{array}{l}\text { Oxide and other minerals dissolve at reduced } \\
\text { conditions, resulting in increased leaching and } \\
\text { organic }\end{array}$ \\
\hline Fire & Conversion of goethite or hematite to magnetite \\
\hline Artifacts & $\begin{array}{l}\text { Change nutrient concentrations, } \mathrm{pH} \text {, base saturation, } \\
\text { mineralogy, etc.; addition of artificial minerals not } \\
\text { present in natural soils; }\end{array}$ \\
\hline \multicolumn{2}{|l|}{ Biological } \\
\hline $\begin{array}{l}\text { Domesticated plants and } \\
\text { Animals }\end{array}$ & $\begin{array}{l}\text { Change in composition of soil organic matter; change } \\
\text { in soil biota }\end{array}$ \\
\hline Invasive species & $\begin{array}{l}\text { Change in composition of soil organic matter; change } \\
\text { in soil biota }\end{array}$ \\
\hline Pesticides & Change or elimination of soil biota \\
\hline
\end{tabular}

Source: Howard, 2017 


\section{Human as a soil forming factor}

The state factor approach to soil genesis is a theoretical framework in which soil is characterized in terms of five soil-forming factors, with $S=f(c, 1, o, p, t \ldots)$ as the "mathematical" expression.

The equation has never been solved, however Jenny (1941) looked at how one factor changed while the others remained constant. In any given setting, human actions alter one or more of the five soil-forming factors.

Table 5.Impact of anthropogenic activity on soil forming factors

\begin{tabular}{|c|c|}
\hline $\begin{array}{l}\text { Anthropogenic } \\
\text { activity }\end{array}$ & Impact \\
\hline Climate & $\begin{array}{l}\text { Modify temperature and precipitation by adding or withdrawing water } \\
\text { by irrigation or artificial drainage, boosting temperature via fire, global } \\
\text { warming, and sealing soils behind a manmade layer such as pavement, } \\
\text { and so on. }\end{array}$ \\
\hline Organism & $\begin{array}{l}\text { The introduction of cultivated plants and animals, the introduction of } \\
\text { invasive species, and the addition of organic debris such as household, } \\
\text { human, and animal wastes all contribute to devegetation or } \\
\text { deforestation. }\end{array}$ \\
\hline Landscape & Land raising or leveling, excavation, ground subsidence, and terracing. \\
\hline Parent Material & $\begin{array}{l}\text { Removal of some components, such as soluble salts, and artificial } \\
\text { additions of bone, shell, ash, and other artifacts }\end{array}$ \\
\hline Time & $\begin{array}{l}\text { The pedogenic clock is reset to zero when soil is buried beneath fill or } \\
\text { sealed beneath a manmade layer, whereas scalping, excavation, or } \\
\text { mixing and deposition of fill exposes fresh parent materials. }\end{array}$ \\
\hline
\end{tabular}

Source: Howard, 2017

Given that humans differ from other organisms in that they purposefully manage soils independently of other soil-forming variables, and because they employ technology to affect soils on a far larger scale than other organisms. Some people consider humans to be the sixth soil-forming factor because of their combined effects on soil formation. (Dudal, 2005 and Leguedois et al. 2016).

\section{Classification of anthropogenic soils}

\section{USDA Classification of anthropogenic soils}

Anthropogenic soils are classified on the basis of two key characteristics:

$\checkmark$ Parent material

$\checkmark$ The presence of diagnostic horizons 


\subsection{Based on parent material}

\section{Human Altered Material (HAT)}

Humans have purposely mixed or disturbed HAM to a depth of $50 \mathrm{~cm}$, but no indication of it having been moved from outside the pedon has been found. There is no standard horizon nomenclature for identifying material that has been altered by humans. The asterisk symbol (*) is used to indicate them informally. Organic and mineral materials can both be found in HAM. It could contain artifacts used as agricultural additives, such as shells or bones.

\section{Human Transported Material (HTM)}

HTM is a 7.5-cm-thick layer of organic and/or mineral materials that shows signs of human-caused transport and does not originate from the same pedon as the pedon it overlies. The HTM layer rests unevenly on in situ material (e.g., a buried A horizon) and frequently contains non-agricultural artifacts (e.g., concrete). The caret symbol () is used as a prefix in conjunction with master horizons such as $\mathrm{O}, \mathrm{A}, \mathrm{B}$, or $\mathrm{C}$.

Table 6.Diagnostic horizons of anthropogenic soils

\begin{tabular}{|l|c|l|}
\hline \multicolumn{1}{|c|}{ Epipedon } & \multicolumn{1}{|c|}{$\begin{array}{c}\text { Horizon } \\
\text { designation }\end{array}$} & \multicolumn{1}{|c|}{ Description } \\
\hline Ochric & $\mathrm{A}, \wedge \mathrm{A}$ & $\begin{array}{l}\text { Organic-poor eluvial layer }<10-25 \mathrm{~cm} \text { thick } \\
\text { with base saturation }<50 \%\end{array}$ \\
\hline Anthropic & $\mathrm{A}, \wedge \mathrm{A}$ & $\begin{array}{l}\text { A 25-cm-thick organic-bearing mineral layer } \\
\text { developed in HAM or HTM that either covers } \\
\text { the mine or contains artifacts. }\end{array}$ \\
\hline Plaggen & $\wedge \mathrm{A}$ & $\begin{array}{l}\text { Organic-rich layer of HTM } 50 \mathrm{~cm} \text { thick } \\
\text { containing artifacts and spade marks }\end{array}$ \\
\hline
\end{tabular}

\begin{tabular}{|l|l|l|}
\hline Endopedon & Horizon designation & \multicolumn{1}{|c|}{ Description } \\
\hline Agric & Bh, Bw, Bt a & $\begin{array}{l}\text { Illuvial horizon } 10 \mathrm{~cm} \text { thick located directly } \\
\text { below a plow layer containing illuvial } \\
\text { silt/clay/humus }\end{array}$ \\
\hline Albic & E & $\begin{array}{l}\text { Light-colored eluvial subsoil horizon leached of } \\
\text { clay and free iron-oxides to such a degree that } \\
\text { the color of the horizon is mostly due to } \\
\text { uncoated sand and silt particles }\end{array}$ \\
\hline
\end{tabular}




\begin{tabular}{|l|l|l|}
\hline Argillic & Bt & $\begin{array}{l}\text { Illuvial horizon } 7.5 \mathrm{~cm} \text { thick, forms as a result } \\
\text { of the translocation of clay from an overlying } \\
\text { eluvial layer }\end{array}$ \\
\hline Cambic & $\mathrm{W}$ & $\begin{array}{l}\text { Mineral horizon of very fine sand, loamy very } \\
\text { fine sand, or finer texture, } 15 \mathrm{~cm} \text { thick with some } \\
\text { weak indication of reddening/gleying }\end{array}$ \\
\hline
\end{tabular}

Source: Soil Survey Staff, 2014

Soil scientists and archaeologists define an artifact as any artificial thing larger than $2 \mathrm{~mm}$ in size found in soil. Although discrete artifacts that are non-persistent and/or non-cohesive are not termed coarse fragments, they are classified as a particular type of coarse fragment. Artifacts are significant because they can obstruct root growth and water circulation, as well as contribute significantly to the soil's trace element and total organic carbon content. Artifacts are a typical feature of anthropogenic soils, with different types depending on the geocultural environment. Brick, cardboard, glass, metal, concrete, paper, and plastic are just a few examples.
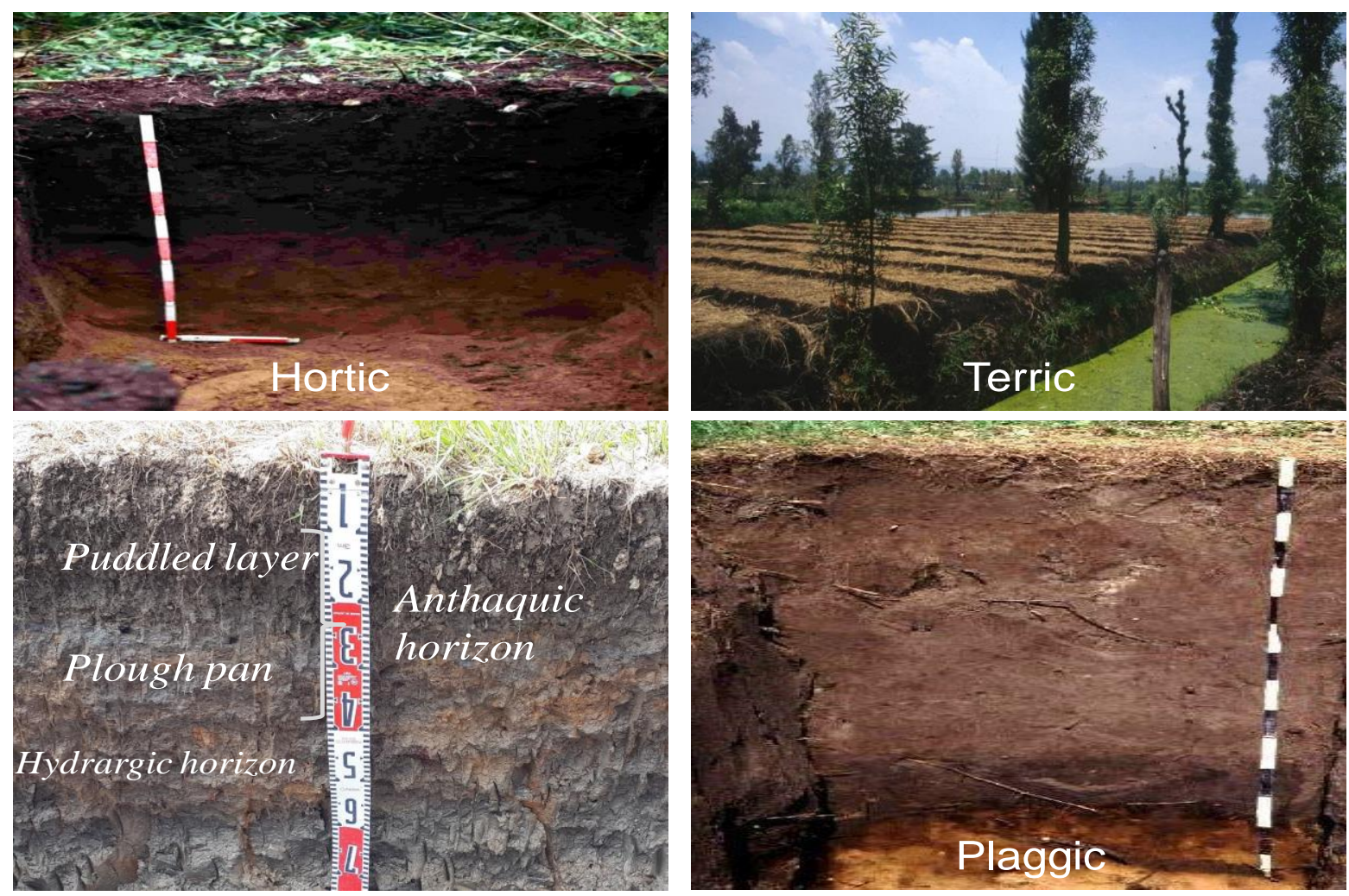

Fig 6.Diagnostic horizons of anthrosols 
Entisols are a type of anthropogenic soil that is defined as a mineral soil with little or no evidence of the development of pedogenic horizons. Inceptisols are soils with cambic B horizons found in urban and mine settings. Inceptisols, Alfisols, and occasionally Ultisols are anthropogenic soils with well-developed cambic and argillic strata found on ancient burial mounds.

\subsection{World Reference Base of Soil Resources}

At the highest level of classification, the World Reference Base (WRB) is made up of 32 Reference Soil Groups (RSGs) (IUSS Working Group 2006, 2015). The RSG name is coupled with a set of qualifiers and supplemental qualifiers to form the second level of classification. According to the WRB, anthropogenic soils are classified using ten primary diagnostic strata and components. Many of them are identical to those used in Soil Taxonomy, while the rest are mostly unknown in the United States. At the second level of classification, various qualifiers are utilised to further identify RSGs.

Anthrosol is a naturally occurring soil that has been significantly altered by long-term human contributions of organic and inorganic components. Anthrosols have been discovered in human habitation sites (e.g., kitchen middens, burials) and in regions where agricultural operations have been undertaken for many millennia, maybe from prehistoric times.

Table7.Diagnostic horizons of Anthrosols

\begin{tabular}{|l|l|}
\hline Epipedon & \multicolumn{1}{|c|}{ Horizon designation } \\
\hline Anthraaquic & $\begin{array}{l}\text { A puddled layer and a plough pan compose an anthropogenic } \\
\text { horizon in paddy soils. }\end{array}$ \\
\hline Hortic & $\begin{array}{l}\text { Deep cultivation and long-term organic material inputs result } \\
\text { in an anthropogenic horizon. }\end{array}$ \\
\hline Irragric & $\begin{array}{l}\text { Anthropogenic horizons on raised ground developed over } \\
\text { time when irrigation water containing fine particles of } \\
\text { inorganic and organic debris was continuously added. }\end{array}$ \\
\hline Plaggic & $\begin{array}{l}\text { Long-term additions of plaggen have built up an } \\
\text { anthropogenic organic-rich horizon on raised soil. }\end{array}$ \\
\hline Pretic & $\begin{array}{l}\text { Long-term inputs of organic materials, such as biochar, have } \\
\text { resulted in an anthropogenic organic-rich horizon. }\end{array}$ \\
\hline Terric & $\begin{array}{l}\text { Anthropogenic horizon on higher land created by long-term } \\
\text { inorganic material additions }\end{array}$ \\
\hline
\end{tabular}




\begin{tabular}{|l|l|}
\hline \multicolumn{1}{|c|}{ Endopedon } & \multicolumn{1}{c|}{ Horizon designation } \\
\hline Hydragric & $\begin{array}{l}\text { Anthropogenic horizon in paddy soils with redoximorphic } \\
\text { characteristics }\end{array}$ \\
\hline Thionic & $\begin{array}{l}\text { Weathering of sulphides caused by strip mining or artificial } \\
\text { draining of swamp soils produces an extremely acidic } \\
\text { horizon. }\end{array}$ \\
\hline
\end{tabular}

Source: IUSS working group, 2015

The presence of materials made, altered, or exposed by human technology that would not otherwise be present at the Earth's surface characterises a Technosol. Urban soils associated with residential and industrial landscapes that contain extensive technogenic artefacts, manufactured (paved) land, and mine soils are all included in the Technosol RSG. Technosols are neogenetic anthropogenic soils with pedogenic properties that show modern human technology's effect. Technosols are anthropogenic soils developed in HTM with 20\% artefacts by volume in the upper $100 \mathrm{~cm}$, or with technic hard material (made layer) at or near the ground surface. (Dazzi and papa, 2015)

Table 8.Different Qualifiers of technosols

\begin{tabular}{|l|l|}
\hline \multicolumn{1}{|c|}{ Qualifiers } & \multicolumn{1}{|c|}{ Description } \\
\hline Ekranic & $\begin{array}{l}\text { Having a } 5 \mathrm{~cm} \text { radius of technic hard material from the soil } \\
\text { surface }\end{array}$ \\
\hline Linic & $\begin{array}{l}\text { Soils that have a geomembrane within } 100 \mathrm{~cm} \text { of the soil } \\
\text { surface that entirely separates the soil material into two } \\
\text { different soils. }\end{array}$ \\
\hline Urbic & $\begin{array}{l}\text { Within } 100 \mathrm{~cm} \text { of the surface, a layer }>30 \mathrm{~cm} \text { thick } \\
\text { comprising }>20 \text { percent by volume artifacts of rubble and } \\
\text { rubbish from human activity }\end{array}$ \\
\hline Spolic & $\begin{array}{l}\text { Having a } 25 \mathrm{~cm} \text { thick layer of industrial waste artifacts } \\
\text { within } 100 \mathrm{~cm} \text { of the surface containing }>20 \text { percent by } \\
\text { volume (mine spoil, dredgings, rubble, etc.) }\end{array}$ \\
\hline Garbic & $\begin{array}{l}\text { Having a } 25 \mathrm{~cm} \text { thick layer of organic waste objects within } \\
100 \mathrm{~cm} \text { of the surface that contains }>20 \text { percent by volume }\end{array}$ \\
\hline
\end{tabular}

Source: Peter Schad, 2018 

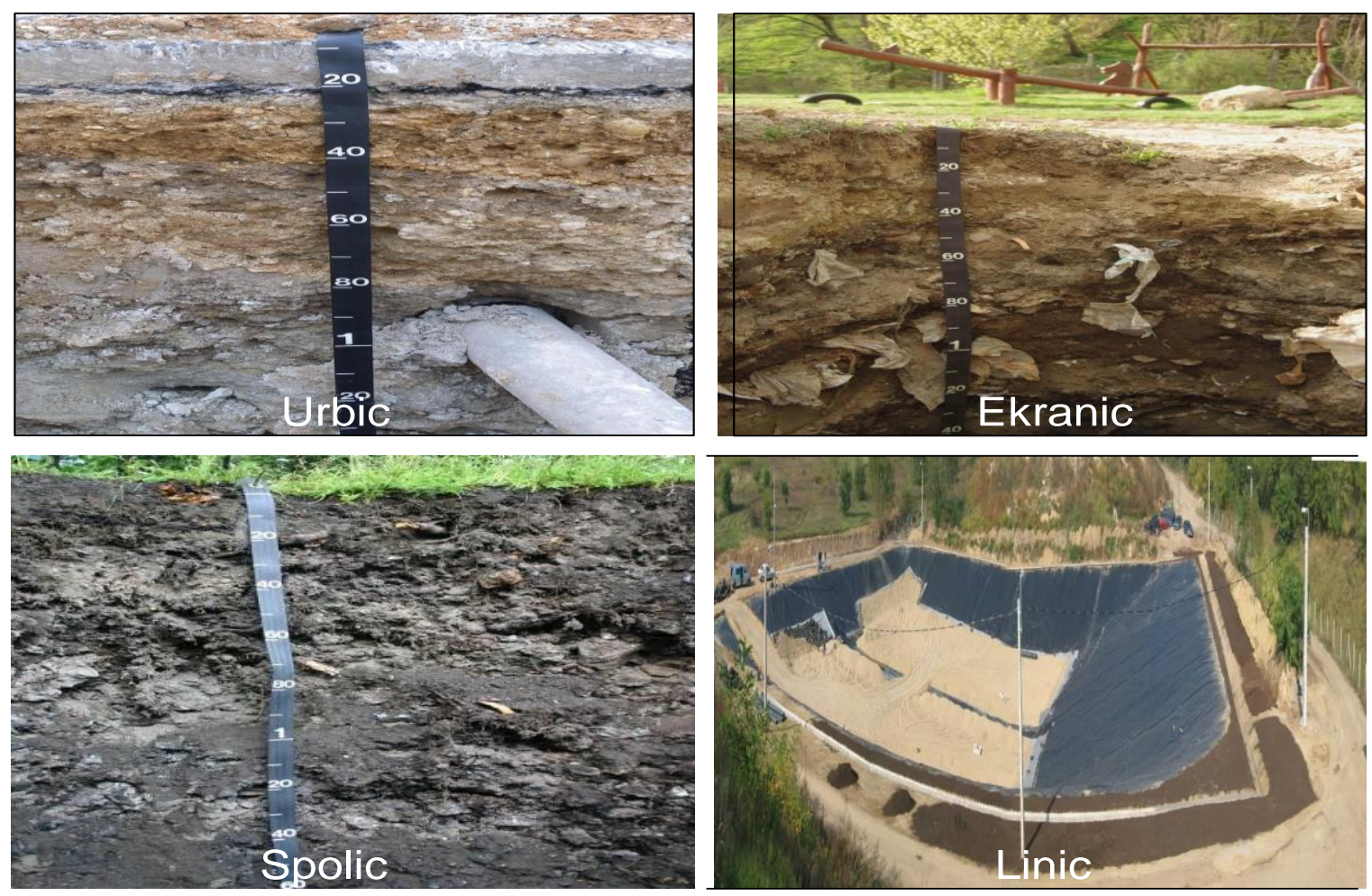

Fig 7.Different types of technosols

\section{The Significance of Accelerated Erosion in the Anthropocene}

Weathering's production of soil particles and solutes (W) surpassed transport-related losses of particles and solutes via erosion and subsurface runoff, according to Gilbert (1877). (T). W liberates mineral particles and inorganic solutes, $\mathrm{T}$ eliminates a fraction of them, and landscapes collect the rest. Agriculture and land-use development, on the other hand, have increased dramatically. Wilkinson and McElroy (Wilkinson and McElroy, 2007). As the Earth transforms from a natural to a human-natural globe, Gilbert's T relates to W. At $1000 \mathrm{~m}$ elevation, where most people live, grow crops, and interact with the terrestrial environment, erosion has been increased nearly fully. Natural geologic erosion,on the other hand, is primarily caused by high mountain slopes of 4,000 to 6,000 .

According to Panagos et al. (2015), 21st-century soil losses due to erosion averaged $2.5 \mathrm{Mg} \mathrm{ha}^{-1} \mathrm{y}^{-1}$, while Verheijen et al. (2009) estimated soil formation at $1.4 \mathrm{Mg} \mathrm{ha}^{-1} \mathrm{y}^{-1}$. The rapid particle movement and particle deposition caused by Gilbert's $\mathrm{T}$ growing overall relative to $\mathrm{W}$ has had huge effects for Earth's land and aquatic ecosystems meters. 


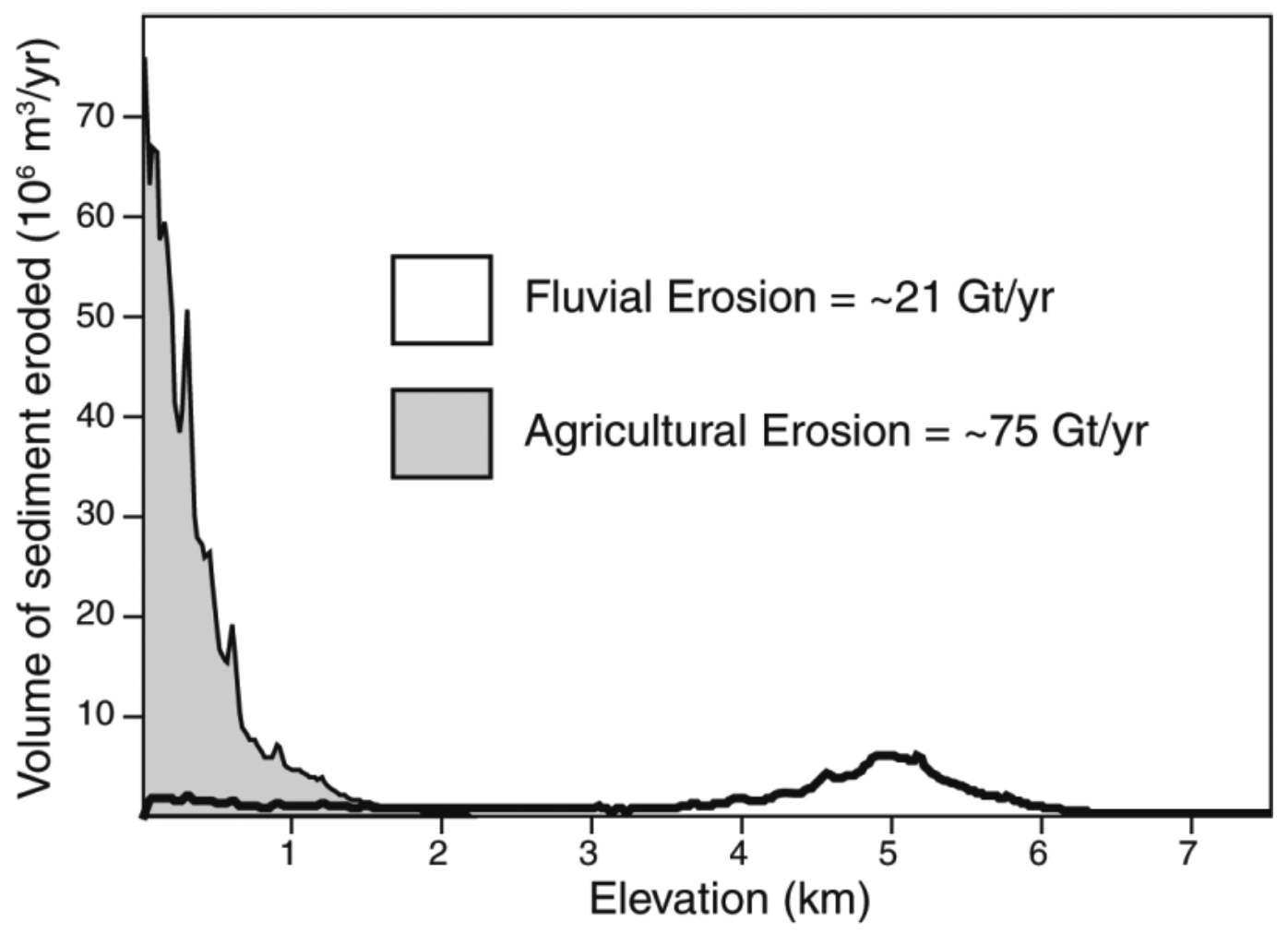

Fig 8. Soil erosion on Earth as a function of elevation and from natural fluvial and agricultural sources

The natural ageing process connected to geological erosion mechanisms is well stored in the distribution tails at larger scales, according to statistical study of gradient and slope distributions (Bonetti et al., 2017). A natural process like this can be influenced by agricultural-driven rapid erosion, which results in significant changes in distribution tails at smaller sizes. The observed morphological variations between disturbed and undisturbed sites were linked to a breakdown in the natural equilibrium between soil creep and runoff erosion mechanisms. (Boneti, 2019)

\section{Anthropocene- a new context for social innovation and transformations to sustainability}
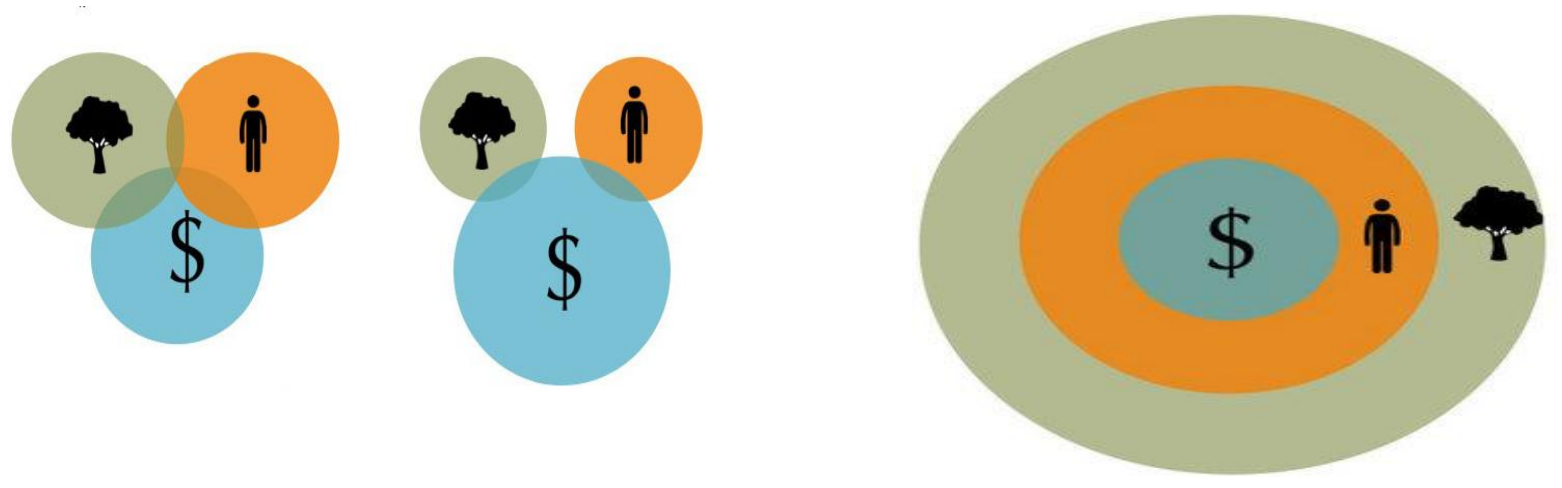

Fig 9.Triple Bottom line thinking 
The social, environmental, and economic pillars commonly associated with sustainable development and "triple bottom line" thinking have frequently resulted in trade-off decisions that either ignore or significantly favour the economic. Economic and social factors must be viewed as nested within ecosystems rather than as distinct parts to be traded off. (Olsson et al., 2017).

\section{Anthropocene in ecology and conservation}

In the year 2000, the word 'Anthropocene' was coined to describe the current epoch in which human impacts are at least as important as natural processes (Corlett, 2015). The Anthropocene idea has centred attention on human-dominated habitats and novel ecosystems in ecology, but it has created a controversial debate in conservation biology about the continued relevance of conventional biocentric goals.

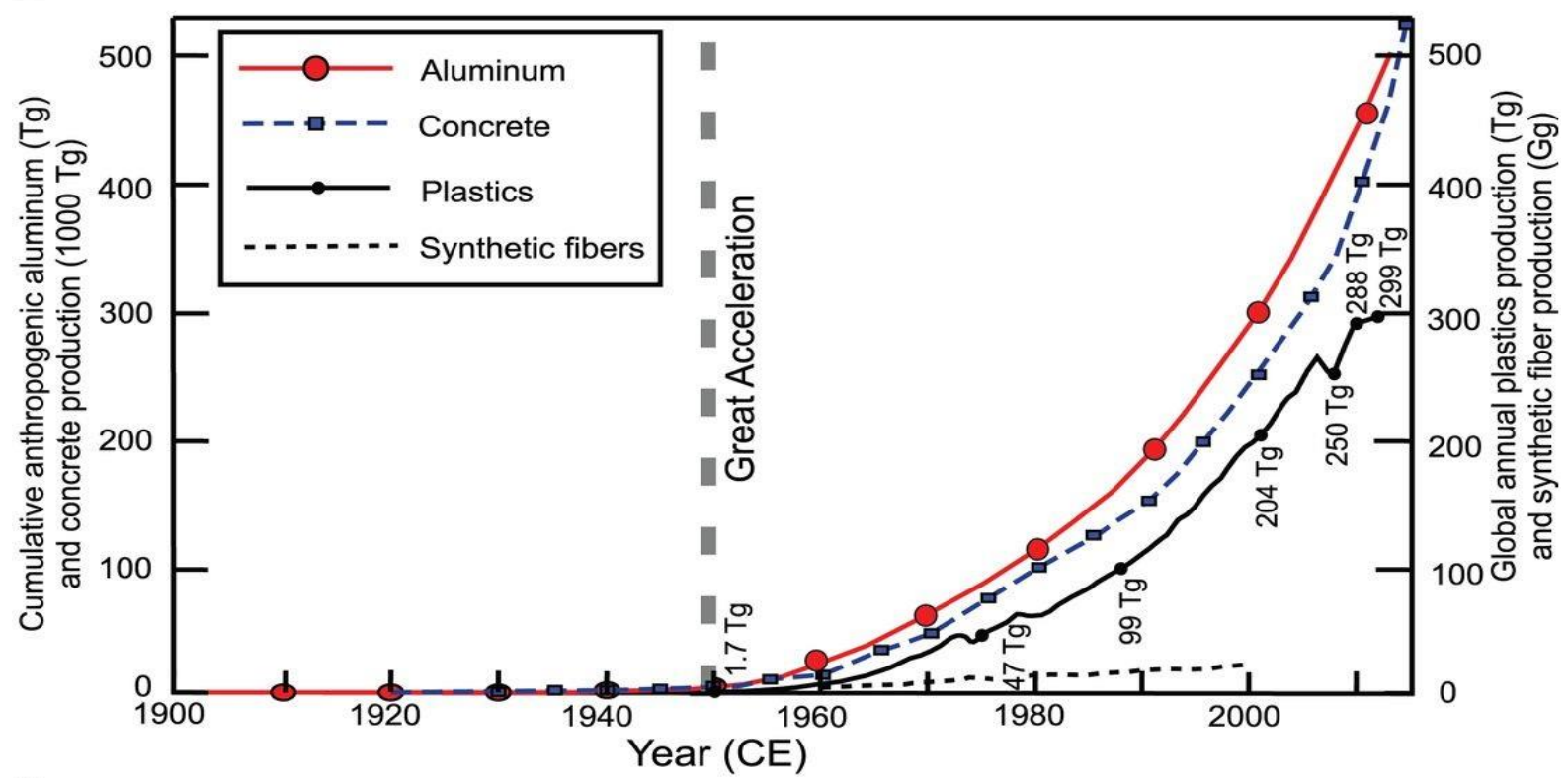

Fig 10.Production of new anthropogenic materials

Humans have created materials previously unknown on Earth, such as pottery, glass, bricks, and copper alloys, throughout millennia. Remains of these materials can be found as a durable and extensive geological signature that is time-transgressive, indicating human migration. In comparison, since $1950 \mathrm{CE}$, elemental aluminium has produced 98 percent of its total global production of $500 \mathrm{Tg}$, which was nearly unknown in its native form before the 19th century. From World War II (1939-1945CE) onward, concrete, which was created by the Romans, became the principal building material. More than half of the 50,000 $\mathrm{Tg}$ of concrete ever made (Fig.) was produced in the last 20 years (1995-2015), equivalent to 1 $\mathrm{kgm}^{2}$ of the planet's surface. Concrete and aluminium are commonly used in terrestrial environments, particularly in metropolitan areas. Similarly, from the 1950s to the present, the production of novel organic polymers (plastics), which were first developed in the early 1900s, has increased dramatically. (Waters et al., 2016). 


\section{Conclusion}

The basic science of pedology, the study of natural soil formation, is evolving into the science of anthropedogenesis in the Anthropocene. The Soil Survey Manual has been updated to include descriptions of human altered and transported materials (HAHT soils), the 2014 Soil Taxonomy Keys has been updated to include over two decades of ICOMANTH work, and the WRB now recognizes soils altered by agriculture, urban, and industrial development. In Soil Taxonomy, a new soil Order that represents "anthropogenic soils" will most likely be added in the future. Several ideas to identify the groups of anthropogenic soils have been offered, but no broad agreement has been established as of yet. The most serious issue is how to deal with the reality that there is only a basic mathematical understanding of how human forcings affect soils. Anthropedology is the future of pedology, a revived discipline that draws on past pedology but goes from "human as outsider" to "human as insider." The human must change from a soil-disturbing to a soil-forming agent in pedology.

\section{References}

Amundson, R., Heimsath, A., Owen, J., Yoo, K., Dietrich, W.E. 2015. Hill slope soils and vegetation. Geomorphology 234, 122-132.

Bonetti, S., Richter, D. D., Porporato, A. 2019. The effect of accelerated soil erosion on hillslope morphology. Earth Surface Processes and Landforms.

Brecheisen, Z. S., Cook, C. W., Heine, P. R., Richter, D. D. 2019. Micro-topographic roughness analysis (MTRA) highlights minimally eroded terrain in a landscape severely impacted by historic agriculture. Remote Sensing of Environment 222, 78-89

Buol SW, Southard RJ, Graham RC, McDaniel PA.2011.Soil genesis and classification. Pp 543-544. Wiley-Blackwell, West Sussex, UK.

Brady, N.C. and Weil, R.R.,2008. Prospects for global soil quality as affected by human activities. The nature and properties of soils. $14^{\text {th }}$ edition. Pearson: Prentice Hall, Upper Saddle River, NJ.

Capra, G. F., Ganga, A., Grilli, E., Vacca, S., Buondonno, A.2015. A review on anthropogenicsoils from a worldwide perspective. Journal of Soil and Sediment.

15, 1602-1618.

Corlett, R. T. 2015. The Anthropocene concept in ecology and conservation. Trends in Ecology and Evolution 30, 36-41.

Crutzen, P. J. 2016. Geology of mankind. Nature 415

Crutzen, P. J., Stoermer, E. F. 2000. The Anthropocene. IGBP Newsletter 41, Royal Swedish Academy of Sciences, Stockholm, Sweden.

Dazzi, C. and Papa, G.L. 2015. Anthropogenic soils: General aspects and features. European Ecocycle society, 1(1), pp.3-8.

Dudal, R. 2005. The sixth factor of soil formation. Eurasian Soil Science C/C of Pochvovedenie, 38, p.60.

Edgeworth, M., Richter, D. D., Waters, C., Haff, P., Neal, C., Price,S. J. 2015.Diachronous beginnings of the Anthropocene: The lower bounding surface of anthropogenic deposits. Anthropocene Review 2, 33-58 
Hilgard, E. W. 1860. Report on the Geology and Agriculture of the State of Mississippi. State Printer, Jackson, MS, USA.

Howard, J. 2017a.The Nature and Significance of Anthropogenic Soils. Springer, In Anthropogenic Soils. pp. 1-9.

Howard, J., 2017b. Human Impacts on Soils. Springer, In Anthropogenic Soils, pp. 53-62.

Howard, J., 2017c. Classification of anthropogenic soils. Springer, In Anthropogenic Soils. pp. 95-113.

IUSS Working Group. 2006. World Reference Base for soil resources 2006. World Soil Resources Report 103.p. 145. Food and Agriculture Organization United Nations,

Rome, Italy

IUSS Working Group WRB. 2015. World Reference Base for soil resources 2014, update 2015 International soil classification system for naming soils and creating legends for soil maps, World Soil Resources Reports, 106. Food and Agriculture Organization United Nations, Rome, Italy Jenny, H. 1941. Factors of Soil Formation. Macmillan, New York, NY, USA

Leguédois, S., Séré, G., Auclerc, A., Cortet, J., Huot, H., Ouvrard, S., Watteau, F., Schwartz, C. and Morel, J.L. 2016. Modelling pedogenesis of Technosols. Geoderma, 262, pp.199-212. Malhi, Y. 2017. The concept of the Anthropocene. Annual Review of Environment and Resources, 42, pp.77-104.

McNeill, J. R., Winiwarter, V. 2004. Breaking the sod: humankind, history, and soil. Science 304, pp.1627-1629

Olsson, P., Moore, M.L., Westley, F.R. and McCarthy, D.D. 2017. The concept of the Anthropocene as a game-changer: a new context for social innovation and transformations to sustainability. Ecology and Society, 22(2)

Panagos, P., Borrelli, P., Poesen, J., Ballabio, C., Lugato, E., Meus- burger, K., Montanarella,L., Alewell, C. 2015. The new assessment of soil loss by water erosion in Europe. Environmental Science and Pollution, 54, pp. 438-447.

Richter, D.D., Bacon, A.R., Brecheisen, Z. and Mobley, M.L. 2015. Soil in the Anthropocene. In IOP Conference Series: Earth and Environmental Science 25 (1).

Richter, D.D. 2020. Game Changer in Soil Science. The Anthropocene in soil science and pedology. Journal of Plant Nutrition and Soil Science, 183(1), pp.5-11.

Richter, D. D., Yaalon, D. 2012. "The changing model of soil' revisited. Journal of Soil Science Society of America, 76, pp. 766-778

Sandor, J. A. 2006. Ancient Agricultural Terraces and Soils, in Warkentin, B. P. (ed.):

Footprints in the Soil. Elsevier, Oxford, UK, pp. 505-534

Schad, P. 2018. Technosols in the World Reference Base for Soil Resources-history and definitions. Soil Science and Plant Nutrition, 64(2), pp.138-144.

Schaetzl, R. J., Thompson, M. L. 2015. Soils: Genesis and Geomorphology, $2^{\text {nd }}$ Edition. Cambridge University Press, Cambridge, UK

Soil Survey Staff. 2014. Keys to soil taxonomy, pp -372, $12^{\text {th }}$ edition. U.S. Department of Agriculture, Natural Resources Conservation Service. 
Steffen, W., Leinfelder, R., Zalasiewicz, J., Waters, C.N., Williams, M., Summerhayes, C., Barnosky, A.D., Cearreta, A., Crutzen, P., Edgeworth, M. and Ellis, E.C.2016. Stratigraphic and Earth System approaches to defining the Anthropocene. Earth's Future, 4(8), pp.324-345.

Steffen, W., Rockström, J., Richardson, K., Lenton, T.M., Folke, C., Liverman, D., Summerhayes, C.P., Barnosky, A.D., Cornell, S.E., Crucifix, M. and Donges, J.F. 2018. Trajectories of the Earth System in the Anthropocene. Proceedings of the National Academy of Sciences, 115(33), pp.8252-8259.

Verheijen, F. G. A., Jones, R. J. A., Rickson, R. J., Smith, C. J. 2009. Tolerable versus actual soil erosion rates in Europe. Earth Science Review. 94, 23-38.

Warkentin, B. P. 2006. Footprints in the Soil. Elsevier, Oxford, UK

Waters, C.N., Zalasiewicz, J., Summerhayes, C., Barnosky, A.D., Poirier, C., Gałuszka, A., Cearreta, $\quad$ A., Edgeworth, M., Ellis, E.C., Ellis, M. and Jeandel, $\quad$ C., $\quad 2016 . \quad$ The Anthropocene is functionally and stratigraphically distinct from the Holocene. Science, 351 (6269).

Wilkinson, B. H., McElroy, B. J. 2007. The impact of humans on continental erosion and sedimentation. Geological Society of America Bulletin. 119, 140-156

Zalasiewicz J. 2008. The Earth After Us. Oxford: Oxford University Press 